\title{
CITA MENUJU IDEAL MORAL AL-QUR'AN (Kajian atas Neo-Modernisme Fazlur Rahman)
}

\author{
Hudan Mudaris"
}

\begin{abstract}
According to Fazlur Rabman, the interpretation of Qur'an verses should go along with the social changes. Meanwbile, still there is a phenomenon on arguing the best solution; maintaining the classical interpretation or building contextual ones. When changing bappened there is a challenge to prove the existence of Qur'an.
\end{abstract}

Kata kunci: teori "ideal moral", neo-modernisme, weltanschaung

\section{A. Pendahuluan}

Dalam wacana pemikiran keislaman, Fazlur Rahman tampil sebagai sosok yang meyakinkan dan cemerlang dalam membangun dan merumuskan metodologi pemahaman atas agamanya (Islam). Syafi'i Maarif bahkan mengklaim, bahwa Rahman adalah seorang yang paling bertanggung jawab dalam masalah pembaruan pemikiran Islam secara total dan tuntas.

Syafi'i Maarif memang tidak menjelaskan apa yang ia maksud dengan pembaruan pemikiran Islam secara total dan tuntas itu, serta dalam konteks apa ia bicara demikian. Namun, dari kerangka berpikir yang dibangun oleh Rahman serta rumusan metodologi sistematisnya dalam memahami sumber-sumber Islam (al-Qur'an

*) Hudan Mudaris, M.Si adalah staf pengajar Sekolah Tinggi Ilmu Tarbiyah Yogyakarta (STITY) Wonosari, peneliti LAKPESDAM Nahdlatul Ulama D.I. Yogyakarta. 
dan Sunnah), seperti terlihat dalam metode "gerak ganda" dan teori "ideal moral" serta "legal-formal"-nya di atas.

Untuk menemukan gambaran metodologis pembaruan Rahman di atas, makalah ini lebih diorientasikan untuk menelusuri rumusan metodologis Rahman dalam melihat teks kitab suci al-Qur'an serta implikasi-implikasinya yang terlihat jelas dalam gagasan-gagasan yang diproduksinya. Dalam penelusuran itu-tanpa mengesampingkan elemen-elemen sejarah yang ikut berperan dalam proses pemproduksian metode dan gagasangagasannya-diupayakan dapat memetakan secara detail mode of thought Rahman.

\section{B. Biografi dan Perjalanan Intelektual Rahman}

Rahman dilahirkan pada tahun 1919 di daerah barat laut Pakistan, ketika itu anak benua Indo-Pakistan masih belum terpecah menjadi dua negara. Anak benua ini dalam sejarah dikenal telah melahirkan pemikir-pemikir Muslim yang kritis dan liberal, seperti Syah Wali Allah, Sir Sayyid, Amir Ali, Parwez, dan Muhammad Igbal. ${ }^{1}$ Sir Sayyid misalnya, adalah tokoh yang memberi pendasaran atas sikap kritis terhadap hadis. Sebelum para sarjana Barat, seperti Ignaz Goldziher, melakukan kritik konseptual atas hadis, Sir Sayyid telah mengutak-atik hadis. Dan kemudian hal itu dielabori kembali dengan kritis oleh Parwez, hingga Parwez sampai pada kesimpulan yang ekstrim bahwa hadis tidak bisa dipandang dari Nabi karena mengandung banyak hal yang tidak masuk akal, terlalu antropomorfis, dan memalukan secara moral. ${ }^{2}$ Suasana intelektual yang demikian itu nantinya ikut mewarnai perkembangan corak intelektual Rahman.

Seperti diakui Rahman sendiri dalam catatan otobiografinya, ia dilahirkan dalam sebuah keluarga yang sangat religius, mempraktekkan ibadah-ibadah keislaman, seperti shalat, puasa,

1 Taufik Adnan Amal, Islam dan Tantangan Modernitas: Studi atas Pemikiran Hukum Fazlur Rabman (Bandung: Mizan, 1996), hal. 79.

${ }^{2}$ Ibid., hal. 86. 
dan lainnya tanpa meninggalkannya sekalipun. Dalam usia yang ke-10 tahun, ia sudah dapat menghafal Al-Qur'an di luar kepala. ${ }^{3}$ Ayah dan ibunya sangat berpengaruh dalam membentuk watak dan keyakinan awal religius Rahman. Dari ibunya ia memperoleh pengajaran secara langsung tentang nilai-nilai kebenaran, cinta, kasih sayang, dan kesetiaan. Sedangkan dari ayahnya ia memperoleh sikap keterbukaan terhadap perubahan dan modernitas. Ayahnya memang seorang alim yang terdidik dalam suatu pola pemikiran tradisional. Tapi tidak seperti kebanyakan alim tradisional pada masanya, yang memandang pendidikan modern sebagai racun baik keimanan maupun moralitas, ayah Rahman berkeyakinan bahwa Islam harus memandang modernitas sebagai tantangan-tantangan maupun kesempatan-kesempatan. ${ }^{4}$ Pandangan inilah yang kemudian menitis pada diri Rahman.

Secara kultural keluarga Rahman hidup dalam tradisi mazhab Hanafi, sebuah mazhab Sunni yang lebih kental dengan corak rasionalis dibandingkan dengan tiga mazhab Sunni lainnya, yakni Syafi'i, Maliki, Hanbali, dan Maliki. Namun meskipun dibesarkan di kalangan tradisionalis bermazhab Hanafi, seperti diungkap Taufik, Rahman sejak umur belasan tahun telah keluar dari kungkungan batas-batas mazhab yang sempit itu dan mengembangkan pikirannya secara bebas. ${ }^{5}$

Pada tahun 1933, Rahman pindah dari tempat tinggal leluhurnya menuju Lahore, yang saat itu disebut "Kota Taman dan Perguruan Tinggi". Di kota ini ia belajar secara formal di sekolah modern. Di samping itu, di rumah, Rahman mendapatkan pengajaran privat dari ayahnya untuk mata pelajaran-mata pelajaran tradisional dalam kajian keislaman, sebagaimana yang

${ }^{3}$ Lihat Fazlur Rahman,, "An Authobiographical Note". Artikel ini telah diterjemahkan ke dalam bahasa Indonesia oleh Ihsan Ali Fauzi. Lihat "Membangkitkan Kembali Visi al-Qur an: Sebuah Catatan Otobiografis,” Al-Hikmah, No. 6, Juli Oktober 1992 hal. 59; juga telah disunting dalam buku, Fazlur Rahman, Cita-cita Islam, terj. Sufyanto dan Imam Musbikin (Yogyakarta: Pustaka Pelajar, 2000), hal. 3.

${ }^{4}$ Ibid., hal. 4.

${ }^{5}$ Amal, Islam dan Tantangan., hal. 78. 
pernah didapatkan ayahnya dari perguruan tinggi Deaband, di wilayah utara India. ${ }^{6}$ Sebuah madrasah bergengsi yang didirikan oleh Muhammad Qasim Nanotawi pada tahun 1867 . $^{7}$

Namun dari pelajaran ayahnya yang berakar tradisional itu tampaknya tidak banyak mempengaruhi Rahman, selain menanamkan rasa keterikatan dan keterlibatannya terhadap Islam. Ia sendiri pernah mengisahkan bahwa pada masa kecil, ayahnya sering memberikan pelajaran hadis, di samping fikih, tetapi sejak umur belasan tahun, Rahman telah skeptis terhadap hadis. Sikapnya ini yang kemudian dikembangkan dan diartikulasikan secara sistematis dalam banyak karya intelektualnya. ${ }^{8}$

Usai menamatkan pendidikan menengah, Rahman melanjutkan studinya di Departemen Ketimuran Universitas Punjab. Pada 1942 ia berhasil menyelesaikan pendidikannya di universitas tersebut, dan memperoleh gelar MA di bidang sastra Arab. Saat meraih gelar tersebut dan sedang belajar untuk program $\mathrm{Ph} . \mathrm{D}$ di Lahore, Rahman pernah diajak Mawdudi untuk bergabung dalam "Jama'at al-Islami" dengan syarat harus meninggalkan studinya. Sebab bagi Mawdudi, semakin banyak belajar, semakin beku kemampuan-kemampuan praktis. ${ }^{9}$ Tapi ajakan itu oleh Rahman ditolak, dan ia memutuskan untuk melanjutkan studinya karena lebih mencintai studi. Pertemuan itu menggambarkan bagaimana Rahman dan Mawdudi awalnya telah mempunyai hubungan yang cukup akrab. Tapi, belakangan Rahman tampil menjadi kritikus atas pemikiran keagamaan Mawdudi yang paling berani dan tangguh.

\section{Belajar di Barat (tahun 1950-an)}

Di samping menolak tawaran Maududi, Rahman juga membuat sikap yang sangat mengejutkan sekaligus kontroversial:

\footnotetext{
${ }^{6}$ Rahman, Cita-cita Islam, hal. 4 .

${ }^{7}$ Lihat catatan kaki nomor 3 dalam Taufik Andan Amal, Tantangan, hal. 80.

${ }^{8}$ Ibid., hal. 80.

${ }^{9}$ Fazlur Rahman, Islam and Modernity: Transformation of an Intellectual Tradition (Chicago and London: University of Chicago Press, 1982), hal. 117. Edisi Indonesia diterjemahkan oleh Ahsin Muhammad, Islam dan Modernitas (Bandung: Pustaka, 1982).
} 
ia memutuskan untuk melanjutkan studinya ke Inggris. Keputusan macam itu merupakan langkah yang berani. Sebab pada waktu itu ada anggapan umum yang menyatakan bahwa merupakan suatu yang aneh jika seorang Muslim pergi ke Barat untuk belajar Islam di sana. Kalaupun toh ada yang melakukan, resikonya adalah tidak akan diterima kembali di negeri asalnya. ${ }^{10}$ Bagi Rahman mencari pengalaman di sarang orientalis jauh lebih penting ketimbang mematuhi kesan umum masyarakat yang tidak jelas pijakannya itu.

Ada satu alasan mendasar mengapa Rahman mengambil sikap demikian itu, yakni ketidakpuasan Rahman atas mutu Pendidikan Tinggi Islam di negara-negara Muslim yang metodenya lebih bersifat tekstual dan hafalan. Sementara itu di Barat diajarkan dan dikembangkan model berpikir kritis, sistematismetodis. Pada suatu kesempatan di Inggris, Rahman pernah ditanya oleh pendeta Hindu, Sir S. Radhakrishnan, "Mengapa Anda tidak ke Mesir saja, tapi malah ke Oxford?" "Studi-studi Islam di sana sama tidak kritisnya dengan di India” Jawab Rahman.

Dalam konteks kesadaran macam itulah Rahman kemudian mengkritik dengan pedas model pendidikan di lembaga-lembaga tersebut. Tentang Al-Azhar, misalnya, ia mengkritik bahwa lembaga pendidikan itu dalam kenyataannya "mewakili sosok akhir pemikiran abad pertengahan dengan beberapa modifikasi baru dan kecil-kecilan", serta posisi intelektual-spiritualnya tetap statis. Dengan nada sinis Rahman membuat metafor: "laksana sebuah gunung salju yang walaupun tumbuh membesar dengan menyerap segala macam materi lewat ukurannya yang besar semata, namun perlahan-lahan meleleh dan tinggal sisa-sisa bekasnya saja."11

Benar, pada 1946, akhirnya Rahman menunaikan niatnya untuk melanjutkan studinya di Oxford University, Inggris. Di samping mengambil kuliah-kuliah formal, ia rajin mempelajari

${ }^{10}$ Amal, Islam dan Tantangan, hal. 81.

"Rahman, Islam and Modernity, hal. 99-100. 
bahasa-bahasa Barat. Atas ketekunannya setidaknya ia menguasai sembilan bahasa: Latin, Yunani, Inggris, Perancis, Jerman, Turki, Persia, Arab dan Urdu. ${ }^{12}$ Penguasaannya atas bahasa tersebut pada perkembangannya sangat membantu upayanya dalam memperdalam dan memperluas wawasan keilmuannya, khususnya dalam studi-studi Islam, lewat penelusuran terhadap literatur-literatur keislaman yang ditulis para orientalis dalam bahasa-bahasa mereka.

Pada tahun 1950, Rahman berhasil merampungkan studi doktoralnya di Oxford dengan disertasi tentang Ibnu Sina. Setelah meraih doctor of philosophy (D.Phil.) dari Oxford University ini ia tidak langsung kembali ke Pakistan yang baru merdeka beberapa tahun dan ini tentunya membutuhkan tenaganya. Mungkin kecemasan bahwa seorang sarjana keislaman yang terdidik di Barat tidak akan diterima kembali atau bahkan dikucilkan di negerinya sendiri, masih menghantui pikiran Rahman, sehingga ia memilih menetap untuk sementara di Barat. Dalam kesempatan itulah ia mengajar di beberapa tempat: di Durham University Inggris; Institute of Islamic Studies, McGill University, Kanada di mana ia menjabat sebagai Associate Professor of Philosophy. Di Kanada inilah Rahman bertemu-kemudian bersahabat dengan baik-W.C. Smith, yang saat itu menjadi direktur Institute of Islamic Studies, McGill University. ${ }^{13}$

\section{Pulang ke Pakistan (tahun 1960-an)}

Di awal dekade 60-an, Rahman kembali ke negeri asalnya, Pakistan. Tampaknya ia telah siap untuk menerima risiko-risiko yang akan dialaminya di Pakistan. Sebab, pertentangan antara kubu modernis dan tradisionalis-fundamentalis di Pakistan telah demikian kental dalam rangka memberikan definisi ideologis bagi Pakistan sebagai sebuah negara Islam. Rahman dengan sangat tegas mengidentifikasi dirinya sebagai sosok modernis dengan pikiran-pikiran kritisnya.

${ }^{12}$ Lihat catatan kaki nomor 10 dalam Amal, Islam dan Tantangan, hal. 81.

${ }^{13}$ Ibid., hal. 82. 
Pada waktu itu ia menjabat selama beberapa waktu sebagai salah seorang staf senior pada Institute of Islamic Research. Lembaga ini didirikan oleh Ayyub Khan, yang kemudian bertindak sebagai pelindungnya, pada 1960. Pada Agustus 1962, Rahman ditunjuk sebagai Direktur lembaga Riset tersebut. Di samping itu, dua tahun kemudian ia juga diangkat sebagai anggota Advisory Council of Islamic Ideology Pemerintah Pakistan.

Penunjukan Rahman menjadi direktur Lembaga Riset Islam, tidak mendapat restu dari kalangan ulama, karena menurut mereka jabatan direktur lembaga tersebut semestinya merupakan hak privilese eksklusif seorang alim yang terdidik secara tradisional. Para ulama tidak pernah memaafkan "dosa" Rahman karena belajar didan berhubungan dengan-Barat. Pandangan-pandangannya yang kritis dan kontroversial membuat mereka kecewa dan sakit hati.

Di kesempatan lain, lembaga riset yang dikelola Rahman berhasil menerbitkan dua jurnal ilmiah: Islamic Studies (berbahasa Inggris), dan Fikr an-Nazr (berbahasa Urdu). Dalam jurnal-jurnal inilah, di samping media-media ilmiah lainnya, Rahman mulai mengemukakan gagasan pembaruannya yang selalu menimbulkan kontroversi. Beberapa kontroversi itu dapat kita lihat misalnya, pandangannya mengenai Sunnah dan Hadis, ordonansi hukum kekeluargaan Muslim, keluarga berencana, riba dan bunga bank, zakat dan pajak, sembelihan mekanis, dan wahyu Tuhan.

Berbagai media massa yang ada di Pakistan membantu melancarkan proses kontroversi pemikiran Rahman tersebut. Puncak dari kehebohan kontroversi itu adalah pernyataan Rahman dalam buku Islam bahwa Al-Qur'an secara keseluruhan adalah Kalam Allah dan dalam pengertiannya yang biasa juga seluruhnya merupakan perkataan Muhammad. ${ }^{14} \mathrm{Pada}$ awal

${ }^{14}$ Fazlur Rahman, Islam (Chicago and London: University of Chicago Press, 1979), hal. 31. Edisi Indonesia diterjemahkan oleh Ahsin Muhammad (Bandung: Pustaka, 1984); lihat juga Fazlur Rahman, "Wahyu Ilahi dan Nabi" dalam Taufik Adnan Amal (penyunting), Metode dan Alternatif Neomodernisme Islam Fažlur Rabman (Bandung: Mizan, 1992), hal. 35 . 
September 1968, bahkan berujung dengan demonstrasi besarbesaran dan aksi mogok total, mulai dari kalangan mahasiswa hingga tukang cukur. Sebenarnya, seperti diungkap John L. Esposito, demo massa itu lebih bersifat politis, tidak ditujukan pada Rahman tetapi untuk menentang Ayyub Khan, presiden Pakistan pada waktu itu. ${ }^{15}$ Akhirnya, Rahman mengajukan pengunduran diri dari jabatan Direktur Lembaga Riset Islam pada 5 September 1968 yang langsung disetujui oleh Ayyub Khan. ${ }^{16}$

\section{Hijrah ke Chicago (tahun 1970-an)}

Setelah mengundurkan diri tersebut, Rahman kemudian hijrah ke Chicago, dan sejak 1970 menjabat sebagai Guru Besar Kajian Islam dalam berbagai aspeknya pada Departemen of Near Eastern Language and Civilization, University of Chicago. Oposisi yang dilakukan oleh kalangan fundamentalis Pakistan telah membuatnya berpikir bahwa ternyata negeri kelahirannya tidak lagi nyaman sebagai tempat mengembangkan kebebasan intelektual yang bertanggung jawab. ${ }^{17}$ Di Universitas Chicago, Rahman menjadi Guru Besar yang sangat dihormati dan dikagumi. Bahkan ketenaran universitas ini sebagai salah satu pusat studi Islam terkemuka di Barat, juga antara lain karena penunjukan kepadanya sebagai Guru Besar.

Rahman dalam sejarahnya memang tampil sebagai tokoh kontroversial. Gagasan-gagasannya mulanya memang banyak dimaki, tapi perlahan-lahan gagasannya itu mulai diterima dan diikuti beberapa kalangan. Setelah tidak kurang selama 18 tahun mengkomunikasikan gagasannya dari Chicago, pada 26 Juli 1988 ia wafat akibat serangan jantung yang kronis. ${ }^{18}$

15John L. Esposito, "Pakistan: Pencarian Identitas Islam" dalam J.L. Esposito (Ed.), Islam dan Perubahan Sosial Politik di Negara Sedang Berkembang, terj. Wardah Hafidz (Yogyakarta: PLP2M, 1985), hal. 286.

${ }^{16}$ Amal, Metode, hal. 15.

${ }^{17}$ Ibid., hal. 16.

${ }^{18}$ Ahmad Syafii Maarif, “Umat Jangan Dipasung," Tempo, 27 Agustus 1988, hal. 84, sebagaimana dikutip Amal, Islam dan Tantangan, hal. 111. 
4. Karya-karya Rahman

Dalam tiga etape perjalanan intelektual tersebut Rahman telah memproduksi karya-karya intelektualnya.

a. Periode awal (dekade 50-an) ketika ia masih di Oxford menulis:

i. Dua karya terjemahan dan suntingan dalam edisi Inggris atas karya monumental Ibnu Sina Kitab an-Najat dan Kitab an-Nafs yang merupakan bagian dari Kitab asy-Syifa' dengan judul, Avicenna's Psychology (1952) dan Avicenna's De Anima (1959).

ii. Prophecy in Islam: Philosophy and Orthodoxy (1958) sebuah karya orisinal yang melakukan penelusuran atas sumber-sumber pemikiran religio-filosofis Islam.

b. Periode Pakistan (dekade 60-an):

i. Islamic Methodology in History (1965), bicara tentang: (1) evolusi historis perkembangan empat prinsip dasar pemikiran Islam: al-Qur'an, Sunnah, ijtihad, dan ijma' dan (2) peran aktual prinsip-prinsip tersebut terhadap perkembangan Islam.

ii. Islam (1966) kajian historis dan interpretatif dalam pengertian Islami, dan gagasan-gagasan neomodernisme Islam.

c. Periode Chicago (dekade 70-an)

i. The Pbilosopby of Mulla Sadra (1975): kajian historis atas pemikiran religio-filosofis Mulla Sadra yang berpijak pada karya monumental Sadra: Al-Asfar al-Arba'ab.

ii. Major Themes of the Qur'an (1980): hasil penulisan ulang tulisan-tulisan Rahman ketika menetap di Pakistan dan setelah kepindahannya ke Chicago.

iii. Islam and Modernity: Transformation of an Intellectual Tradition (1982): hasil dari proyek riset Universitas Chicago, "Islam and Social Change". Penulisannya dimulai pada 1977 dan selesai pada 1978. Oleh Rahman mulanya buku ini diberi judul Islamic Education and Modernity, kemudian dirubah oleh penerbit demi kepentingan pasar.

iv. Artikel-artikel di berbagai jurnal ilmiah. 


\section{Teori Fazlur Rahman tentang Sejarah Pembaharuan Pemikiran Islam}

Pada penghujung dekade 1970-an, Rahman membagi dialektika perkembangan pembaruan pemikiran yang muncul di dunia Islam ke dalam empat gerakan. ${ }^{19}$

a. Revivalisme pra-modern, gerakan yang muncul pada abad ke-18 dan 19 di Arabia. Gerakan ini tidak pernah bergumul dengan Barat. Cirinya:

i. Keprihatinan mendalam terhadap degradasi sosio-moral umat Islam dan usaha untuk mengubahnya;

ii. Imbauan kembali kepada Islam sejati, mengusir takhayul, meninggalkan gagasan tentang kemapanan dan finalitas mazhab hukum serta berupaya melakukan ijtihad;

iii. Imbauan untuk mengenyahkan corak pre-deterministik, dengan kekuatan bersenjata (jihad) jika perlu.

b. Modernisme klasik, gerakan yang muncul pada pertengahan abad ke-19 dan awal abad ke-20 dengan mengambil ide-ide revivalisme pra-modernis di bawah pengaruh Barat. Hal baru dalam gerakan ini adalah perluasannya atas "isi" ijtihad-seperti hubungan antara akal dan wahyu, pembaruan sosial khususnya dalam bidang pendidikan dan status wanita, serta pembaruan politik dan bentuk-bentuk pemerintahan yang representatif dan konstitusional-lantaran kontaknya dengan pemikiran Barat. Menciptakan kaitan yang baik antara pranatapranata Barat dengan tradisi Islam melalui Qur an dan Sunnah merupakan suatu prestasi yang besar dan tidak artifisial.

c. Neo-revivalisme (revivalisme pasca modernisme klasik): gerakan yang mendasarkan pada basis pemikiran modernisme klasik bahwa Islam mencakup segala aspek kehidupan manusia, baik individu ataupun klasik. Namun karena usahanya membedakan

\footnotetext{
${ }^{19}$ Lihat Fazlur Rahman, "Islam: Challenges and Opportunities" dalam Islam: Past Influence and Present Cballenge, A.T. Welch dan P. Cachia (Eds.), (Edinburgh: Edinburgh University Press, 1979), hal. 315-125; Amal, Metode dan Alternatif, hal. 18.
} 
diri dengan Barat, maka neo revivalisme merupakan reaksi atas modernisme klasik. Mereka tidak menerima metode modernisme klasik, sayangnya mereka tidak mampu membangun metodologi apapun untuk menegaskan posisinya kecuali membedakan Islam dari Barat.

d. Neomodernisme: gerakan yang mengembangkan sikap kritis terhadap Barat ataupun terhadap warisan kesejarahannya sendiri. Jika keduanya tidak dikaji secara objektif, maka keberhasilannya menghadapi dunia modern menjadi suatu kemustahilan. Rahman mengklaim dirinya mewakili kelompok keempat ini. Tanpa harus mengalah kepada Barat secara membabi-buta atau menafikannya, maka tugas utamanya menurut Rahman adalah mengembangkan metodologi yang tepat untuk mempelajari Qur'an guna memperoleh petunjuk bagi masa depan.

Metodologi yang hendak dibangun Rahman tersebut didasarkan pada suatu konsepsi teoretik bahwa yang ingin dicari dan diaplikasikan dari al-Qur'an menuju kehidupan umat manusia adalah bukan pada arti tekstualnya, tetapi lebih pada konsepsi pandangan dunianya (weltanschaung). Oleh karena itu ia kemudian membangun konsepsi teoretik yang membedakan dengan tegas antara tujuan-tujuan atau "ideal moral" Al-Qur'an dengan ketentuan "legal spesifiknya". Ideal moral yang dituju oleh Al-Qur'an bagi Rahman lebih pantas untuk diterapkan ketimbang ketentuanketentuan legal spesifiknya. Konsepsi inilah yang kemudian akan memberikan reformasi signifikan dalam tradisi pemikiran dan pemahaman Islam.

Karena itu ordonansi Ilahi yang bertalian dengan sektor "sosial", bagi Rahman memiliki suatu bidang "moral" dan suatu bidang "legal spesifik". Yang terakhir, bidang legal spesifik, bagi Rahman merupakan transaksi antara keabadian Kalam Allab dan situasi ekologis aktual Arabia pada abad ke-7. Aspek ekologis ini tentu dapat dikenai perubahan, asalkan bidang moral yang ada di balik ketentuan legal spesifik, yang merupakan respon terhadap 
situasi ekologis, tetap terjaga. Bagi Rahman keabadian kandungan legal spesifik al-Qur'an terletak pada prinsip moral atau nilainilai yang dikandungnya, bukan pada ketentuan-ketentuan harfiyahnya. ${ }^{20}$ Dan pada konsepsi inilah, bagi Rahman tujuan yang ingin ditegakkan oleh al-Qur`an.

\section{Metode Penafsiran al-Qur'an ala Fazlur Rahman}

Untuk mengusung konsepsi teoretiknya itu, Rahman kemudian menyusun metodenya secara sistematik. Dalam sebuah artikel: "Islamic Modernism: Its Scope, Method, and Alternative", yang ia tulis pada 1970, terlihat rumusan metodis yang menjadi bagian perangkat penting dalam proses penafsiran al-Qur`an dan perumusan hukum: ${ }^{21}$

1. Memanfaatkan "analisis historis" yang serius dan jujur untuk menemukan "makna" teks Al-Qur'an. Aspek metafisis dari ajaran Al-Qur'an mungkin tidak menyediakan dirinya dengan mudah untuk dikenakan terapi historis, tetapi bagian sosiologisnya menurut Rahman pasti menyediakan dirinya. Pertama, Al-Qur`an harus dipelajari dalam tatanan kronologisnya. Dengan pemeriksaan atas bagian-bagian wahyu paling awal, bagi Rahman akan diketahui ketetapan dan pranata yang dibangun belakangan. Langkah metode ini akan banyak menyelamatkan: (1) penafsiran-penafsiran artifisial yang berkembang di kalangan modernis; (2) menetapkan makna rinciannya dan makna keseluruhan dari pesan Al-Qur`an secara sistematis dan koheren.

2. Kemudian membedakan antara "ketetapan legal" Al-Qur'an dan "sasaran" serta "tujuannya", yang hukum diabdikan kepadanya. Misalnya, mengapa kesaksian dua wanita sebagai pengganti

\footnotetext{
${ }^{20}$ Fazlur Rahman, Islam and Modernity, hal. 12; Major Tbemes of the Quran, bab III, hal. 37.

${ }^{21}$ Fazlur Rahman, "Islamic Modernism: Its Scope, Method, and Alternative", International Journal of Midle Eastern Studies, Vol I, 1970, kemudian disunting dan diterjemahkan dalam bahasa Inonesia dengan artikel-artikelnya yang lain oleh Sufyanto dan Imam Musbikin, Cita-cita, hal. 52-54; lihat juga, "Gagalnya Modernisme Islam", Islamika, no. 2, OktoberDesember 1993, hal. 13.
} 
kesaksian seorang laki-laki? "Tujuannya" Agar wanita yang satunya dapat mengingatkan wanita lainnya, jike ia melupakannya (Q.S. AlBaqarah [2]: 282)

3. Sasaran dan tujuan Al-Qur'an dipahami dengan memberikan perhatian yang penuh terhadap latar sosiologisnya, yakni lingkungan di mana Nabi bergerak dan beraktivitas. Hal ini diupayakan untuk menghindari tafsir Al-Qur'an yang subjektif. Di sinilah kemudian Rahman membangun konstruksi etika moral sebagai dasar-dasar universal Al-Qur'an.

Secara konseptual Rahman kemudian membuat rumusan definitif langkah-langkah metodologis yang ia sebut dengan "Gerakan Ganda": gerak dari situasi sekarang ke masa al-Qur`an diturunkan, dan kembali lagi ke masa kini. Gerak yang pertama terdiri dari dua langkah: ${ }^{22}$

1. Seseorang harus memahami arti dan makna dari suatu pernyataan tertentu dengan mempelajari situasi atau problem historis di mana pernyataan tersebut merupakan jawabannya. Sebelum mempelajari teks-teks spesifik dalam sinaran situasi spesifiknya, suatu kajian umum mengenai situasi makro dalam batasan masyarakat, agama, adat dan kehidupan secara menyeluruh di Arabia dan sekitarnya harus dilakukan. Ini digerakkan untuk memahami al-Qur'an secara utuh maupun dalam batasan-batasan ajaran spesifik yang merupakan respon terhadap situasi spesifik.

2. Menggeneralisasikan jawaban-jawaban spesifik tersebut dan menyatakannya sebagai pernyataan yang memiliki tujuan moral-sosial umum yang dapat disaring dari teks spesifik alQur'an dalam sinaran latar belakang sosio-historis dan rationes legis ('ilal al-aḅkām) yang sering dinyatakan.

Sedangkan gerakan kedua adalah proses yang berangkat dari pandangan umum ini ke pandangan spesifik yang harus

${ }^{22}$ Fazlur Rahman, Islam and Modernity, hal. 5. 
diformulasikan dan direalisasikan "sekarang". Artinya yang umum ditubuhkan dalam konteks sosio-historis yang konkret sekarang. Dalam usaha ini, bagi Rahman kajian yang cermat terhadap situasi sekarang dan analisis terhadap berbagai unsur komponennya menjadi penting, sehingga seseorang dapat menilai situasi sekarang dan mengubahnya sejauh yang diperlukan dan mendeterminisasi prioritas-prioritas baru untuk mengimplementasikan nilai-nilai Al-Qur`an secara segar. ${ }^{23}$

Gerakan ganda yang dirumuskan Rahman dalam metodologi sistematisnya di atas secara operasional kemudian bergerak untuk membangun tiga kategori pemetaan: (1) perumusan pandangan dunia Al-Qur'an (weltanschaung); (2)sistematisasi Etika Al-Qur'an. Di sini Rahman misalnya merumuskan secara konseptual mengenai tiga kata kunci: Iman, Islam dan Takwa. Iman yang mempunyai arti: aman, bebas dari bahaya, damai, bagi Rahman tidak sama dengan pengetahuan intelektual atau rasional, tidak hanya bermuara pada hati nurani, tapi harus bermuara pada tindakan. Sedangkan Islam bagian dari iman. Sebab mustahil tanpa iman penyerahan diri pada Tuhan (Islam) terjadi. Adapun Takwa dimaknai sebagai sikap hati-hati terhadap bahaya moral; (3) penubuhan etika Al-Qur'an ke dalam kontesk masa kini. Di sini gerakan kedua dari konsep gerakan gandanya berlaku.

Karena yang dicari-seperti terlihat dalam kerangka teorinya di atas-Rahman adalah weltanschaung al-Qur'an, maka sesungguhnya ia sedang menggali dan sekaligus merumuskan etika ideal Al-Qur'an: sesuatu yang esensial dan terdalam dari $\mathrm{Al}$ Qur'an. Dalam konteks ini Rahman terlihat dengan jelas menggunakan cara pandang filosofis: yakni suatu pencarian dan perumusan secara konseptual "fundamental idea" atas segala sesuatu yang termaktub dalam teks kitab suci. Proses ini dilakukan dengan membongkar unsur-unsur kesejarahan dan warna-warna temporal yang ikut terlibat menghiasi dalam memproduksi berbagai

${ }^{23}$ Ibid., hal. 7. 
konsepsi-konsepsi sistem hukum dalam teks kitab suci itu, kemudian menghujam terhadap nilai-nilai dasar yang terkandung di dalam produk formal hukum tersebut.

Implikasi dari pendekatan yang demikian itu, pemikiranpemikiran Rahman kemudian menjadi tidak saja tampak baru tetapi juga memberikan warna kontroversial pada jamannya. Sebab, pendekatan filosofis ini memberikan keberanian untuk keluar dari cengkraman arti-arti tekstual kitab suci sembari masuk dan menghujam pada makna dan ide fundamental di balik teks, yang hal itu sesungguhnya yang ingin disampaikan kitab suci. Di sini, meskipun dalam proses intelektualnya menghadapi teks kitab suci, Rahman sebenarnya tidak terjebak pada teks dalam merumuskan pendefinisian terhadap produk-produk hukum. Sebab ia selalu bergerak dengan nalar kritisnya mencari nilai-nilai yang fundamental dari teks kitab suci tanpa harus terjebak dengan makna literalnya, dengan mempertimbangkan sejarah (tarikh) yang mempunyai peran dalam proses pemproduksian teks al-Qur'an. Rahman sadar benar bahwa ada teks lain yang mesti dibaca untuk dan dalam merumuskan sebuah konsepsi tentang nilai dan moral yang ingin disampaikan oleh kitab suci; yakni sejarah Arabia masa di mana Al-Qur'an mengalami proses menjadi. Di sinilah tampak bahwa Rahman bergerak lincah dari legal spesifik al-Qur'an menuju ideal moralnya.

\section{E. Implikasi Praktis Metodologi Tafsir Rahman}

Berikut ini dipaparkan beberapa implikasi metodologis penafsiran Rahman dalam memahami beberapa tema-tema penting dalam al-Qur'an.

1. Poligami

Persoalan poligami telah menjadi suatu perdebatan yang menarik. Para ulama klasik sepakat bahwa poligami sesuai dengan al-Qur'an (Q.S. 4: 3) dan praktik kesejarahan masyarakat Muslim yang direstui oleh fikih klasik. Dengan merujuk pada cara berpikir Sir Sayyid dan Amir Ali, Rahman menolak pendapat ulama pada saat itu. 
Frasa "adil” dalam Q.S: 4: 3 sebagai syarat untuk berpoligami mustahil dapat dipenuhi oleh para suami, sebagaimana ditegaskan oleh al-Qur`an sendiri (Q.S. 4: 129).

Rahman tidak sepakat bahwa frasa itu berarti keadilan dan persamaan dalam perlakuan lahiriah serta materi, seperti yang dipahami oleh para ulama saat itu. Bagi Rahman, jika frasa tersebut bermakna demikian, maka al-Qur'an tidak mungkin mengatakan bahwa suami mustahil dapat berlaku adil kepada isteri-isterinya, meski ia sangat menginginkannya (Q.S. 4: 129). Rahman dalam kasus ini sepakat dengan teori Sir Sayyid bahwa frasa "berlaku adil" hanya dapat ditafsirkan sebagai "cinta" dan mendukungnya dengan melengkapi beberapa ayat yang lain (Q.S. 30: 21; 2:187) yang baginya jelas menunjukkan bahwa hubungan semestinya yang dikehendaki Al-Qur'an antara suami dan isteri berlandaskan cinta dan kasih sayang. Karena itu, ketika al-Qur'an mengatakan bahwa adalah mustahil untuk berlaku adil di antara istri-istri, maka secara jelas kitab suci itu menyatakan bahwa adalah mustahil mencintai lebih dari seorang wanita dalam cara yang sama. ${ }^{24}$

Dalam kasus ini, klausa mengenai "berlaku adil" harus mendapat perhatian dan ditetapkan memiliki kepentingan yang lebih mendasar ketimbang klausa "spesifik yang mengijinkan poligami". Tuntutan untuk berlaku adil dan wajar merupakan salah satu tuntutan dasar keseluruhan ajaran Al-Qur’an. Bagi Rahman, dalam konteks soal ini, Al-Qur'an berkehendak untuk memaksimalkan kebahagiaan hidup keluarga, dan untuk tujuan ini dinyatakan bahwa suatu perkawinan monogami secara normal adalah ideal. Tetapi tujuan moral ini harus berkompromi dengan kondisi aktual masyarakat Arab pada abad ke-7, di mana poligami berakardalam dan tegar, sehingga secara legal tidak bisa dihapus seketika karena dimungkinkan akan menghancurkan tujuan moral itu sendiri. ${ }^{25}$

${ }^{24}$ Fazlur Rahman, "Controversy" hal, 416-417 sebagaimana dikutip Amal, Islam dan Tantangan Modernitas, hal. 89; Rahman, Islam, hal. 44.

${ }^{5}$ Idem, "The Impact of Modernity," hal. 121-222. 


\section{Qisas}

Berkaitan dengan qishash, Rahman mengemukakan bahwa AlQur'an (Q.S. 2: 178; 4:92) memperkuat hukum pembunuhan yang telah berjalan dalam masyarakat Arab pra-Islam. Solusi spesifik AlQur'an ini memberi kebebasan kepada keluarga korban untuk memilih antara menuntut balas (qisas) atau meminta sejumlah uang penyelesaian atau ganti rugi (diyat). Di samping itu, Al-Qur'an juga menambahkan pengampunan atau pemberian maaf dari keluarga korban yang dipandang sebagai kebajikan bernilai tinggi. Solusi AlQur'an ini memandang pembunuhan sebagai kejahatan terhadap keluarga, sehingga keluarga tersebut bisa menuntut balas atau diyat. Tetapi di tempat lain, ketika bicara tentang pembunuhan yang dilakukan oleh Qabil atas Habil, Al-Qur'an menyatakan: 'Untuk alasan-alasan inilab Kami tetapkan bagi Bani Israel babwa barangsiapa membunub tanpa bak (yakni membunub seorang yang tak bersalab), maka seakan-akan dia telab membunub selurub manusia; dan barangsiapa menyelamatkan kebidupan seseorang, maka seolab-olab dia telab menyelamatkan selurub manusia. (Q.S. 5: 27-32)

Ayat ini bagi Rahman, jelas menjadikan pembunuhan sebagai suatu kejahatan terhadap kemanusiaan, bukan hnya terhadap keluarga korban. Dengan demikian, solusi Al-Qur'an dalam Q.S. 2: 178 dan 4:92, harus dimasukkan ke bawah prinsip yang memandang pembunuhan sebagai kejahatan kemanusiaan.

3. Perbudakan

Perbudakan di kalangan suku-suku Arab pra-Islam, merupakan fenomena umum yang sudah melembaga dalam budaya. Fenomena ini juga terdapat di daerah-daerah tetangga bangsa Arab. Sumber yang paling umum bagi perbudakan di dalam masyarakat Arab pra-Islam adalah peperangan dan penyergapan antar-suku. Kaum laki-laki, perempuan, dan anak-anak dari suku yang kalah biasanya dibunuh atau ditawan. Jika suku asal tawanan ini tidak mampu menebus mereka, maka para tawanan itu dijadikan budak atau dijual sebagai budak. Budak-budak ini berada sepenuhnya di bawah kekuasaan tuannya. Ia 
tidak diperkenankan melakukan apapun tanpa sepengetahuan dan seijin tuannya.

Saat Islam datang, praktik macam itu masih terjadi. Misi kenabian Muhammad yang bertujuan menciptakan tata sosiomoral yang adil, egaliter, dan berlandaskan iman, bagi Rahman tentu saja tidak dapat membiarkan fenomena tersebut. Namun karena kukuhnya pranata sosial saat itu, menghapuskannya secara mendadak tentu akan menimbulkan gejolak sosial yang besar. Oleh karena itu Al-Qur'an menanganinya secara persuasif. Secara moral, Al-Qur'an menekankan bahwa budak harus dibebaskan (Q.S. 5: 89; 24: 33; 58: 3). Intinya bagi Rahman, bahwa tujuan Al-Qur'an dalam kasus ini adalah agar perbudakan dihilangkan sama sekali. ${ }^{26}$

4. Pelarangan Alkohol

Dalam masalah pelarangan alkohol, para ahli fiqih biasanya menggunakan konsep naskh terhadap konsepsi yang beragam yang ada dalam Al-Qur'an: (1) Alkohol sebagai rahmat Tuhan (Q.S. 16: 66-69) ; (2) Alkohol mengandung manfaat tapi di dalamnya terdapat kejahatan yang besar (Q.S. 2: 219); (3) tidak boleh shalat ketika sedang dalam pengaruh alkohol (Q.S. 4: 43); sebagai suatu hal keji dan perbuatan setan (Q.S. 5: 90-91).

Berbeda dengan ahli fikih klasik, Rahman yang tidak setuju dengan konsep naskb mempunyai pemikiran lain. Proses graduasi pelarangan tersebut bagi Rahman lebih terkait dengan "kondisi masyarakat". Ketika berada di Makkah, bagi Rahman kaum Muslim merupakan komunitas informal yang kecil. Tampak bahwa sebagian mereka tidak mengkonsumsi alkohol pada waktu itu. Setelah orangorang Makkah terkemuka masuk Islam, ada di antara mereka yang minum alkohol. Tapi itu tidak menimbulkan masalah, sebab mereka belum menjadi masyarakat besar. Namun setelah hijrah ke Madinah, mereka tidak saja menjadi suatu masyarakat tetapi telah menjadi semacam negara informal. Minum alkohol waktu itu berkembang masalah. Kesimpulannya, bagi Rahman bahwa ketika manusia

${ }^{26}$ Ibid., 213. 
menjadi sebuah masyarakat, alkohol menjadi membayakan sehingga pengkonsumsiannya pun tidak diperkenankan. ${ }^{27}$

Namun, dengan menggunakan metode yang sama (tarikh dan asbäb al-nuzūil), Jalaluddin Rahmat mempunyai konklusi yang berbeda dan bahkan bertolak belakangan dengan analisis Rahman. Dengan analisis sejarah, memanfaatkan tarikh dan asbäb al-nužul, Rahmat mempunyai kesimpulan bahwa pelarangan khamr sebenarnya telah terjadi sejak awal bi'thab Nabi di Makkah. Kesimpulan Jalal ini berangkat dari sejarah yang menjelaskan tentang peristiwa masuk Islam-nya A'sya ibn Qais. Ketika bermaksud menyatakan masuk Islam di depan Nabi, di tengah jalan ia dicegat oleh Abu Sufyan, Abu Jahal dan orang-orang Quraisy lainnya. "Hai Abu Bashir, Muhammad mengharamkan Zina," kata mereka. "Aku tidak keberatan," kata A'sya. "Abu Bashir, Muhammad mengharamkan khamr," kata mereka lagi dan seterusnya.

Peristiwa itu terjadi di Makkah, ketika Abu Jahal masih hidup. Dalam suatu riwayat lain yang dikeluarkan oleh Thabrani dari Mu'adz ibn Jabal disebutkan bahwa di antara yang pertama kali diharamkan pada permulaan kenabian adalah minuman khamr. Oleh karena itu evolusi sikap terhadap khamr, misalnya yang disimpulkan oleh athThabathaba' ${ }^{28}$ lebih merefleksikan sikap mempertegas dari pelarangan tersebut. Bukan karena perbedaan konteks pengkonsumsian antara yang bersifat individual dalam komunitas informal dengan yang pengkonsumsian dalam masyarakat, seperti yang disimpulkan oleh Rahman.

Rahman memang sangat memperhatikan tarikh dan asbäb alnužul, namun apa yang dilakukan Jalal adalah salah satu contoh di mana penggunaan metodologi yang sama dengan Rahman telah menghasilkan konklusi yang sama sekali berbeda.

${ }^{27}$ Ibid., hal. 215.

${ }^{28}$ Muhammad Husain Ath-Thabathaba'i, Al-Mizan fi tafsir al-Qur'an, Qum: Jama'at al-Mudarrisin, t.t., VI: 135. 


\section{F. Sekelumit Apresiasi}

Dari uraian di atas, tampak bahwa metodologi tafsir yang dibangun oleh Rahman memang merupakan langkah baru. Namun demikian, pembaruan yang dilakukan Rahman itu bukan tanpa menyisakan masalah:

1. Metodologi Rahman sepenuhnya memang bersandar pada sejarah untuk memperoleh "makna teks" dan pada analisis latar sosiologis untuk memahami "sasaran” Al-Qur”an. Namun, kita tahu bahwa terdapat jarak yang sangat jauh antara situasi sosial ketika teksteks itu dilahirkan dengan situasi dewasa ini, ketika teks-teks itu dijadikan rujukan. Pertanyaannya adalah dari mana kita memperoleh informasi tentang situasi masa lalu itu? Dalam konteks ini ada dua sumber yang dirujuk oleh Rahman: (1) bukubuku sejarah (tarikh). Tapi problemnya, bahwa tarikh seringkali ditulis oleh orang yang tidak mempunyai pengetahuan historiografi, dan bahkan mempunyai motif-motif tertentu yang patut dicurigai. "Tuhan memang dapat membuat sejarah, tapi hanya ahli sejarah yang dapat mengubah sejarah"; (2) merumuskan situasi zaman Nabi dari asbāb al-nuzūll. Rahman menyadari pentingnya asbāb al-nuzūil, tetapi di saat yang sama ia juga kritis atas literatur asbāb al-nužul yang (dipandangnya) kacau-balau. Bahkan ia tidak segan-segan menolaknya (hadis) bila dipandangnya bertentangan dengan prinsip umum ajaran Al-Qur’an. Nah, jika demikian, sejauh mana kemudian peran sejarah bagi Rahman yang ditangkap dari dua sumber yang keduanya samasama dikritiknya itu?

2. Apakah asbāb al-nuzūl itu hanya berkenaan dengan peristiwa atau orang yang spesifik atau dapat digeneralisasikan? Para ahli tafsir mempunyai dua bentuk kaidah yang saling bertolak belakang dalam soal ini: al-ibrah bi 'umüm al-lafz̃ la bikbusūs al-sabab dan/ atau al-ibrab bikbușus al-sabab la bi 'umūm al-lafž. Di sini ada kesulitan serius dalam menentukan apakah dalam situasi tertentu, sebab itu khusus dan efek legalnya juga khusus, sedangkan dalam situasi yang lain, sebabnya khusus tapi efek legalnya umum. Apa 
ukuran-ukuran dan kriteria proses pengklaiman itu menjadi berbeda. Kesulitan ini tampaknya belum dituntaskan dalam metodologi tafsir Rahman.

3. Dalam proses perumusan makna Al-Qur'an secara koheren dan kohesif dalam metodologinya, Rahman memanfaatkan analisis semantik. ${ }^{29} \mathrm{Hal}$ ini bisa dilihat misalnya ketika menafsirkan makna-makna atas kata-kata yang mempunyai kecenderungan sama atau berdekatan. Misalnya, dalam Major Themes of the Qur'an ketika menafsirkan kata bayyinab, burbān dan sultān ketika disandarkan pada kata ayat (tanda). Yang pertama, yakni bayyina, berarti tanda yang jelas dan tidak dapat ditolak oleh akal terbuka serta tidak berprasangka; burbān lebih bersifat demonstratif dapat mengalahkan prasangka-prasangka tertentu; dan sultän yang secara harfiyah artinya "otoritas" atau "kekuasaan" mempunyai kekuatan yang secara psikologis sifatnya hampir memaksa, sehingga orang yang semula telah bertekad untuk menolak kebenaran terpaksa menerimanya. Namun metode semantik yang dipopulerkan oleh Toshihiko Izutsu itu bukan tanpa masalah. Sebab bukan tidak mungkin akan terjebak dalam: (1) trial and error ketika mencari kata-kata kunci; (2) rumusan semantic field yang berlainan untuk konsep yang sama.

4. Dalam metode "gerak ganda" dan teori ideal moral, Rahman terlihat ada pengaruh dari pandangan filsafat nilai yang berkembang di Barat, khususnya aliran filsafat objektif yang dikemukakan oleh E. Betti. Yakni teori penafsiran modern yang menegaskan bahwa orang pertama-tama harus memastikan arti yang dimaksud oleh pikiran yang menjadi subjek objek kajian. Tafsir dibawa kembali kepada pikiran yang menciptanya, di mana bentuk-bentuk tersebut merupakan kandungannya yang orisinal,

${ }^{29}$ Langkah-langkah metode semantik secara sederhana dapat dijelaskan: (1) memilih istilah-istilah kunci (key-terms) dari vocabulary al-Qur'an yang dianggap sebagai struktur konseptual dasar dari weltanscbasung Qur'ani, (2) menentukan makna pokok (basic meaning) dan makna nasabi (relational meaning), (3) menyimpulkan weltanschauung yang disajikan konsepkonsep itu dalam suatu kesatuan. Lihat Toshihiko Izutsu, God and Man in the Quran (Tokyo: The Keio Institute of Cultural and Linguistic Studies, 1964), hal. 9-15. 
tidak sebagai butir-butir yang terpisah-pisah, tapi sebagai suatu keseluruhan yang koheren, dan dihidupkan kembali dalam pikiran subjek yang melakukan pemahaman atasnya. Lebih dari itu bagi Rahman seperti yang diuraikannya dalam Islam and Modernity bahwa kesatuan bentuk itu tak dapat dinisbatkan kepada pikiran. Orang juga harus mempertimbangkan situasi terhadap mana ia menjadi respon. Sebab, Al-Qur`an bagi Rahman adalah respon Tuhan melalui pikiran Muhammad-faktor yang telah diremehkan oleh ortodoksi Islam-terhadap situasi historis. Tapi, analisis ini tetap tergantung pada tarikh yang dalam beberapa hal dikritik sendiri oleh Rahman.

5. Metode historis-kronologis yang digunakan Rahman, di mana Al-Qur'an harus dipahami dengan latar belakang kesejarahan (situasi sosio-moral Arab pada abad ke-7) tampaknya ada kaitan erat dengan berkembangan studi tentang kronologi Al-Qur'an yang terjadi di Barat yang berkembang pada 1844. Gustav Weil, dengan karyanya Historich Kritische Einleitung in the Koran, misalnya, telah membangun sistem kronologi yang berbeda dengan sistem kronologi Muslim tradisional. Weil misalnya, membagi surat Makiyyah menjadi tiga bagian: awal, tengah dan akhir. Meskipun pendekatan historis-kronologis Rahman secara jelas diilhami oleh tradisi kajian-kajian AlQur'an Barat, namun ada karakteristik yang membedakan secara substansial antara keduanya. Kajian historis-kronologis Al-Qur'an di Barat umumnya berupaya melacak elemenelemen asing dalam kitab suci tersebut, atau merekonstruksi perkembangan psikologi Muhammad dan makna-makna orisinal Al-Qur'an untuk setiap periodenya. Namun, upaya terakhir ini betul-betul historis dan miskin preskripsi dan interpretasi yang bermanfaat bagi umat Islam masa kini. Sedangkan yang dilakukan Rahman adalah berupaya menangkap tujuan, nilai, dan prinsip umum Al-Qur'an untuk dijadikan petunjuk dalam merekonstruksi pemikiran Islam dewasa ini sebagai suatu kekuatan yang kreatif dan vital. Sehubungan dengan aspek 
hukum Islam, pendekatannya berupaya menyarikan prinsipprinsip yang kemudian ditata secara sistematis, hirarkis, dan koheren sebagai etika Al-Qur'an, yang darinya pranata-pranata legal atau sosial Islam dirumuskan dengan mempertimbangkan kondisi kekinian.

6. Pola dan teknik tafsir Rahman dalam beberapa kasus tertentumisalnya buku Major Themes of the Qur'an-menggunakan teknik maudui dalam penyajiannya dan metode tafsir al-Qur'an bi alQur'an. Hal ini dapat dilihat misalnya ketika ia mengulas kata kunci "adil" dalam masalah poligami. Metode ini yang sering ia sebut "membiarkan Al-Qur' an bicara tentang dan dengan dirinya sendiri". Dan mesti diakui dengan model tafsir yang demikian itu Rahman memang berhasil keluar dari jebakan model tafsir yang bersifat parsial, atomistik, atau bahkan harfiyah sebagaimana yang berkembang di kalangan mufassir tradisional-yang sering ia kritik. Karena yang dicari Rahman adalah "pandangan dunia" Al-Qur an. Dengan model metode "gerakan ganda"-nya itu, ia juga mampu menghindar dari proses pemihakan-pemihakan dan pembenaran terhadap salah satu bentuk penafsiran atau pendapat suatu mazhab dan aliran tertentu.

\section{G. Penutup}

Lepas dari kritik yang dilontarkan kepadanya, Rahman memang telah memberikan aroma (intelektual) baru dalam kajian al-Qur'an. Dan aroma itu nyata-nyata telah diendus oleh pemikir Muslim Indonesia, seperti Nurchlosh Madjid, Syafii Maarif, Munawir Sadzali, Bahtiar Effendy dan beberapa pemikir Muslim Indonesia lainnya. Teori ideal moral-nya telah menjadi suatu alternatif baru dalam memahami kitab suci di era sekarang. Demikian juga model penyajian tafsir maudui dan analisis semantik yang diletakkan dalam kerangka ideal moral Al-Qur'an menjadi demikian menarik bagi generasi selanjutnya, meskipun produk-produk yang dihasilkannya mulanya banyak dibenci dan dimaki-terutama oleh golongan ortodoks (ulama tradisionalis) di Pakistan. 
Tampaknya memang benar, bahwa tidak ada yang langgeng kecuali perubahan. Dan dalam konteks ini, Rahman sepenuhnya menyadari bahwa kontroversi adalah bagian dari konsekuensi kreativitas intelektual yang acapkali memang tidak mungkin dihindari untuk menuju perubahan. Rahman telah merelakan dirinya untuk dimaki dan bahkan diklaim munkir al-Qurian demi sebuah perubahan itu. 


\section{DAFTAR PUSTAKA}

Amal, Taufik Adnan. Islam dan Tantangan Modernitas: Studi atas

Pemikiran Hukum Fazlur Rabman. Bandung: Mizan, 1996.

Izutsu, Toshihiko. God and Man in the Qur'an. Tokyo: The Keio Institute of Cultural and Linguistic Studies, 1964.

L. Esposito, John. "Pakistan: Pencarian Identitas Islam" dalam J.L. Esposito (Ed.) Islam dan Perubahan Sosial Politik di Negara Sedang Berkembang, terj. Wardah Hafidz. Yogyakarta: PLP2M, 1985.

Maarif, Ahmad Syafii. "Umat Jangan Dipasung." Tempo, 27 Agustus 1988.

Rahman, Fazlur. "An Authobiographical Note". Artikel ini telah diterjemahkan ke dalam bahasa Indonesia oleh Ihsan Ali Fauzi “Membangkitkan Kembali Visi Al-Qur'an, Sebuah catatan Otobiografis." Al-Hikmah, No. 6, JuliOktober 1992.

Cita-cita Islam, terj. Sufyanto dan Imam Musbikin (Eds.). Yogyakarta: Pustaka Pelajar, 2000.

. Islam and Modernity: Transformation of an Intellectual Tradition. Chicago and London: University of Chicago Press, 1982.

. Islam. Chicago and London: University of Chicago Press, 1979. 
. "Wahyu Ilahi dan Nabi" dalam Taufik Adnan Amal (penyunting), Metode dan Alternatif Neomodernisme Islam Fazlur Rabman, Bandung: Mizan, 1992.

. "Islam: Challenges and Opportunities" dalam Islam: Past Influence and Present Challenge, A.T. Welch dan P. Cachia (Eds.), Edinburgh: Edinburgh University Press, 1979.

. "Islamic Modernism: Its Scope, Method, and Alternative". International Journal of Midle East Studies, Vol I, 1970.

. "Gagalnya Modernisme Islam.” Islamika, No. 2, Oktober-Desember 1993.

- Tema-tema Pokok Al-Quran, terj. Anas Mahyudin. Bandung: Pustaka, 1995.

Rahmat, Jalaluddin. "Kata Pengantar" dalam Taufik Adnan Amal, Islam dan Tantangan Modernitas: Studi atas Pemikiran Hukum Fazlur Rabman. Bandung: Mizan, 1996. 